\title{
Qualitative and quantitative analysis of rabbit's fat mesenchymal stem cells ${ }^{1}$
}

\author{
Análise quantitativa e qualitativa de células tronco mesênquimais da gordura de coelhos
}

\author{
Marcelo Paulo Vaccari Mazzetti', Isis Sousa Oliveira ${ }^{\text {II }}$, Regiane Miranda-Ferreira ${ }^{\mathrm{III}}$, Grasiele Fauaz ${ }^{\mathrm{IV}}$, Chaibe Nunes Ribeiro ${ }^{\mathrm{II}}$, Paulo \\ Oliveira Gomes" ${ }^{\text {, Paulo Pontes }}{ }^{\mathrm{VI}}$, Alice Teixeira Ferreira ${ }^{\mathrm{VII}}$, Lilian Piñero Eça ${ }^{\mathrm{VII}}$ \\ ${ }^{\text {I } M D, ~ M S c, ~ A s s i s t e n t ~ P r o f e s s o r, ~ D e p a r t m e n t ~ o f ~ P l a s t i c ~ S u r g e r y, ~ L u s i a d a ~ U n i v e r s i t y ~ o f ~ S a n t o s, ~ S a o ~ P a u l o, ~ B r a z i l . ~}$ \\ ${ }^{\text {II } B i o m e d i c a l ~ S c i e n t i s t, ~ M a s t e r ~ S t u d e n t, ~ F e d e r a l ~ U n i v e r s i t y ~ o f ~ S a o ~ P a u l o ~(U N I F E S P), ~ B r a z i l . ~}$ \\ III PhD, Post-Doctoral Fellowship, Department of Pharmacology, UNIFESP, Sao Paulo, Brazil. \\ IV $\mathrm{PhD}$, Scientist Researcher of IPCTRON, Stem Cell Research Institute, Sao Paulo, Brazil. \\ ${ }^{v} \mathrm{PhD}$, Associate Professor, Division of Experimental Surgery, Department of Surgery, UNIFESP, Sao Paulo, Brazil.

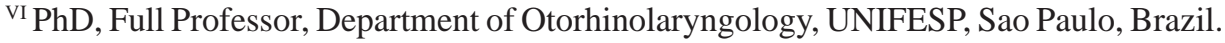 \\ ${ }^{\text {VII }} \mathrm{PhD}$, Associate Professor, Department of Molecular Biology, UNIFESP, Sao Paulo, Brazil. \\ VIII PhD, Biomedical, Scientist, Coordenator of IPCTRON, Stem Cell Research Institute, Sao Paulo, Brazil.
}

\begin{abstract}
Purpose: To present an experimental model of qualitative and quantitative analysis of mesenchymal stem cells from fat of rabbits obtained by lipectomy. The fat could be a great source for obtaining mesenchymal stem cells and to create conditions for repairing injured tissues by bioengineering. Methods: New Zealand rabbits $(\mathrm{n}=10)$ adipose panicle $(2-3 \mathrm{~cm})$ were removed by lipectomy, fragmented and washed with PBS and enzymatically dissociated with trypsin/EDTA. Lately, these cells were incubated in culture medium DMEM and after 20 days, was performed quantitative analysis of the accession of first and second mesenchymal cells in cell culture bottles. Results: The fat total cells (CTF) were $1.62 \times 10^{6} \mathrm{cell} / \mathrm{s} / \mathrm{mL}$ and presented $98 \%$ of viability. These cells were taken for cultivation and after 20 days were counted $2.88 \times 10^{6}$ cells $/ \mathrm{mL}$ MSC. The same was done and after 20 days we quantified $4.28 \times 10^{6}$ cells $/ \mathrm{mL} \mathrm{MSC.} \mathrm{Conclusion:}$ The lipectomy of adipose panicule is a very satisfactory method to extract stem cells from fat, quantitatively and qualitatively.
\end{abstract}

Key words: Lipectomy. Stem Cells. Fats. Rabbits.

\section{RESUMO}

Objetivo: Apresentar um modelo experimental de análise qualitativa e quantitativa de células tronco mesênquimais proveniente da gordura de coelhos obtido por lipectomia. A gordura poderia ser uma grande fonte de obtenção de células tronco mesenquimais, criando condições para a reparação de tecidos lesados. Métodos: Foram removidos os panículos adiposos $(2-3 \mathrm{~cm})$ da região cervical de Coelhos Nova Zelândia $(\mathrm{n}=10)$ por lipectomia. Os panículos foram fragmentados e lavados com PBS e, posteriormente, dissociados enzimaticamente com tripsina / EDTA. As células extraídas do panículo adiposo foram incubadas em meio de cultura DMEM e após 20 dias, foi realizada uma análise quantitativa da adesão de primeira e segunda passagem das células mesênquimais em garrafas de cultura. Resultados: Foram extraídas 1,62 x106 cel/ mL células totais de gordura (CTG) with $98 \%$ de viabilidade. Essas células foram levadas para o cultivo e após 20 dias, foi realizada a primeira passagem (1pd) sendo quantificadas 2,88 x $10^{6}$ cel/mL células tronco mesênquimais (CTM). Na segunda passagem (2pd) foi obtido 4,28 x10 cel/mL CTM. Conclusão: A lipectomia do paniculo adiposo é um método muito satisfatório para extrair células tronco a partir de gordura, quantitativamente e qualitativamente.

Descritores: Lipectomia. Células-Tronco. Gorduras. Coelhos.

${ }^{1}$ Research performed at Stem Cell Research Institute - IPCTRON and Otorhinolaryngology Advance Science Institute - ICAO, Sao Paulo, Brazil.

\section{Introduction}

Scientific and medical experts have the hope to promoting the legendary concept of regenerative medicine to develop therapies restoring injured tissues and acting on the nervous system lesions central $^{1,2}$. This hope becomes more real each day with the use of

advanced technologies such as cell culture, cell therapy, gene therapy and bioengineering, and the adult stem cells (ASC) source of these therapies.

The ASC defined as cells "wild" have the ability to selfrenew and to differentiate into specialized cells ${ }^{3}$ (Figure 1). 


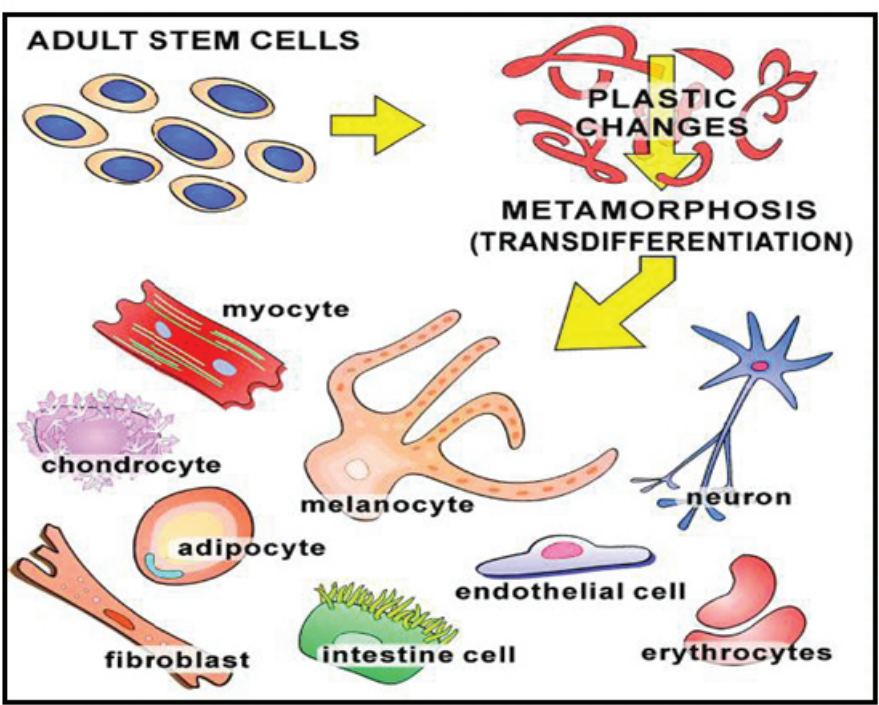

FIGURE 1 - The pluripotential ASC. (Modified from Leri et al. ${ }^{13}$ )

These cells can be found in various niches such as bone marrow, peripheral blood, umbilical cord blood and placental (SCUP), dental pulp, hair follicle and fat, the latter objective of this study. The ASC are divided into two groups: mesenchymal stem cells (MSC) and hematopoietic stem cells (HSC).

MSC found in the bone marrow, also called stromal stem cells, represent $0.01 \%\left(10^{-2}\right)$ to $0.001 \%\left(10^{-3}\right)$ of nucleated bone marrow cells. These cells have great capacity for renewal and can differentiate into connective tissue cells such as osteoblasts, condroblasts, adipocytes, fibroblasts and myoblasts ${ }^{3,4}$.

The HSC are derived from mesoderm ${ }^{5}$. The hematopoietic progenitors accumulate around the blood islands initially, migrating to the fetal liver reaching the bone marrow ${ }^{6,7}$.

In the past 20 years, therapy with ASC of umbilical cord has been used successfully in patients with deficiency in bone marrow. The umbilical cord blood offer advantages over the bone marrow, it does not require a perfect compatibility with human leukocyte antigen (HLA). Moreover, this tissue shows a lower incidence of rejection, can be used allogeneic ${ }^{8}$. However, to obtain ASC of umbilical cord becomes limited, as can be gained only after the birth of the individual.

In this sense it is necessary to obtain ASC alternative sources, such as the adipose tissue presented in this study ${ }^{9-12}$. Therefore, the objective of this study was to perform a qualitative and quantitative analysis of mesenchymal stem cells extracted from fat tissue of rabbits by lipectomy.

\section{Methods}

This study was approved by the Research Ethics Committee of the Federal University of Sao Paulo (UNIFESP). New Zealand rabbits were used $(\mathrm{n}=10), 3$ months, weighing approximately $3.5 \mathrm{~kg}$ from the animal colony of the Institute of Applied Sciences in Otorhinolaryngology (ICAO), Sao Paulo.

\section{Collection of adipose tissue}

The animals were submitted to general anesthesia with ketamine and zoletil $(0.4 \mathrm{ml} / \mathrm{kg}$ each $)$, by intramuscular injection. Subsequently, a longitudinal incision was performed 2 to $3 \mathrm{~cm}$ in the dorso-medial line, where is located the adipose panicle, in which the removed fat desired (lipectomy) (Figure 2).

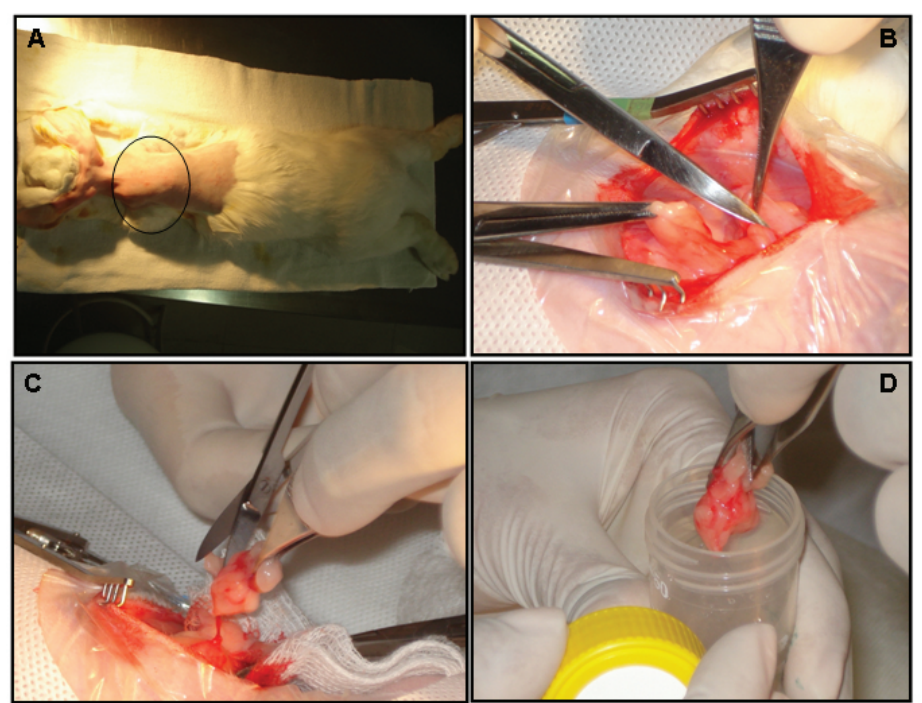

FIGURE 2 - Figures representing. A. dorsal region of rabbit; B. incision of rabbit dorsal region exposing the fat; $\mathbf{C}$. collecting fat from dorsal region; D. Fat on tube with solution of phosphatebuffered saline (PBS)

\section{Separation, cultivation and quantification of ASCs}

After collection, the adipose tissue was fragmented (explant technique) into small pieces (about $1 \mathrm{~cm}$ ) and washed with PBS supplemented with penicillin and streptomycin (1\%) (Figure 3). Subsequently, the fragments were enzymatically dissociated with trypsin / EDTA. After the enzymatic process the material was subjected to centrifugation to the rupture of adipocytes to obtain a button of blood cells from the total fat (CTF) which were counted in a Neubauer chamber. Then were the qualitative part of the study through the cell viability using the dye trypan blue, which is associated to DNA when cell membrane rupture. After confirmation of cell viability, these cells were incubated in culture medium DMEM (high glucose, supplemented with fetal bovine serum and 10\%) at $37^{\circ} \mathrm{C}$ with $5 \% \mathrm{CO}_{2}$. After 20 days, was performed quantitative analysis of the accession of mesenchymal cells (MSC 1pd) in cell culture bottles.

By the enzymatic method (trypsin + EDTA) performed the resuspension of MSC to wrap them in two bottles of the second culture passage (MSC 2pd), and again after 20 days quantify them in a Neubauer chamber.

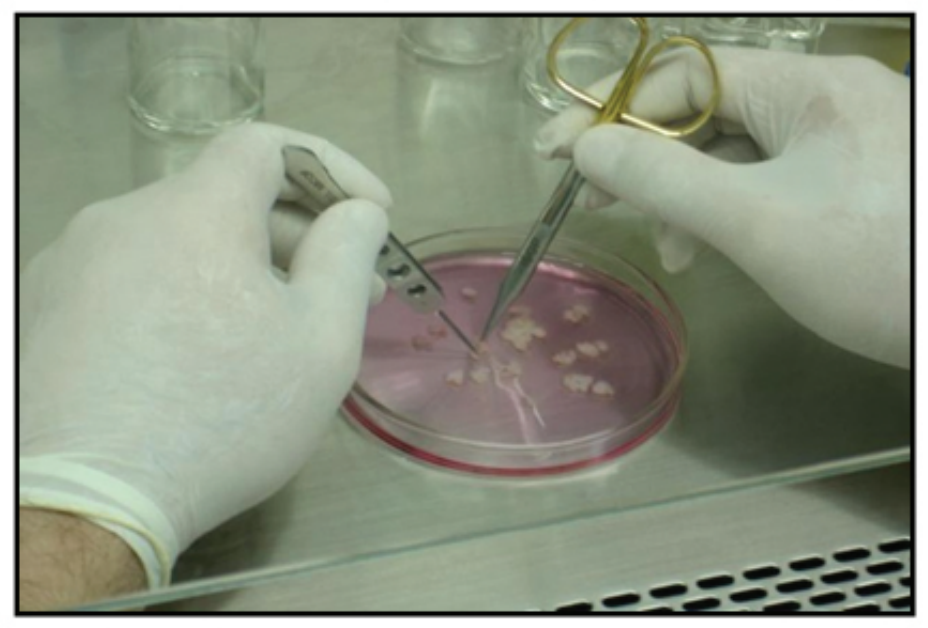

FIGURE 3 - Technique of explants of adipose tissue extracted by lipectomy 


\section{Results}

Quantitative analysis of blood cells of total fat (CTF) before and after culture MSCs

After extraction of CTF, the counting was done in Neubauer chamber which were $1.62 \pm 0.17\left(\times 10^{6} \mathrm{cel} / \mathrm{mL}\right) \mathrm{CTF}$. These cells were taken for culture and after 20 days were counted $2.88 \pm 0.24\left(\mathrm{x} 10^{6}\right.$ $\mathrm{cel} / \mathrm{mL}) \mathrm{MSC}(1 \mathrm{pd})$. These cells were resuspended with trypsin and placed in two bottles which were kept in culture for another 20 days and counted again, quantified $4.28 \pm 0.36\left(\times 10^{6} \mathrm{cel} / \mathrm{mL}\right) \mathrm{MSC}(2$ pd), as shown in Figure 4.

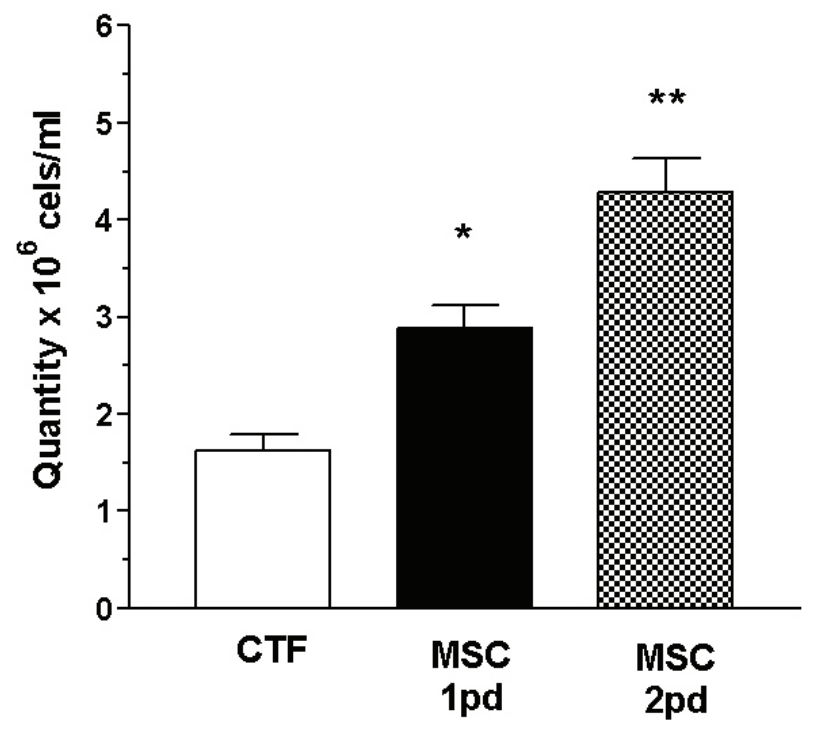

FIGURE 4 - Histogram representing the total cells extracted from adipose panicle rabbit (CTF) and cultivated mesenchymal stem cells after first passage (MSC - 1pd) and second passage (MSC - 2pd). The columns and bars respectively indicate mean \pm standard error of mean of cells from 10 rabbits. Statistically different from the CTF, $* 0.001$ and $* * \mathrm{p} \leq \mathrm{p} \leq 0.0001$ (Student t-test).

Qualitative analysis of mesenchymal stem cells from adipose tissue (MSC)

\section{$\underline{\text { Cell viability }}$}

The CTF (Figure 5) and MSC (data not show) cell viability was done by the reaction with Trypan Blue showing a viability of $98 \%$.

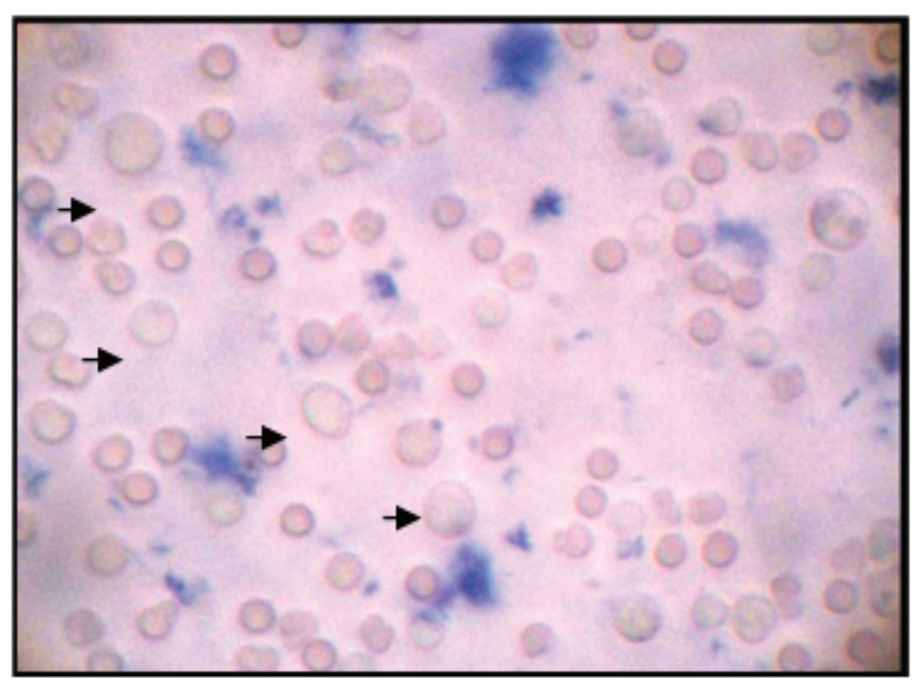

FIGURE 5 - Figures represent the cell viability of CTF with trypan Blue. The arrows represent CTF who are colorless.

\section{Discussion}

This study showed that the enzymatic treatment of rabbit adipose panicle with Trypsin / EDTA resulted in obtaining a large number of blood cells of total fat (CTF). Unfortunately these cells can not be characterized as mesenchymal and hematopoietic cells by using optical microscopy. Because of the population of cells extracted of adipose panicule observed in microscope show appearance of mononuclear and granular cells, we called them by blood cells from total fat (CTF). This work has shown that we can extract $1.62 \times 10^{6}$ cells $/ \mathrm{mL}$ of CTF from adipose panicule with good viability. In the same way Forriol and Esparza ${ }^{14}$ suggest that fat we can extract $4 \times 10^{7}$ cell $/ \mathrm{mL}$ of CTF.

Despite we have obtained a good number of CTF, we can also amplify these cells using a culture method. These cells, when maintained in culture in an appropriate medium, were amplified by $77 \%$ (on relation of CTF) showing a good option to apply these cells to repair injuries. Because of a few studies of fat stem cells, we can not compare exactly the proliferation of these cells types. However, other authors have amplified by about $40 \%$ the blood cells extracted from bone marrow when these cells were maintained on culture ${ }^{14-16}$.

The cells on culture were also show to be able to adhere on culture bottle, extending and converging like a tissue, forming a fibroblastoid colony (CFU-F), like other authors have observed ${ }^{13-}$ 16.

Is important to note that the second passage also increase the quantity of MSC by $164 \%$ (on relation of CTF) showing that these cells have a good capacity of proliferation, like other authors have observed ${ }^{20-24}$. These authors have also observed that these cells maintain the same physiology until five passages ${ }^{23,24}$.

\section{Conclusion}

The fat can be an excellent alternative way to obtain stem cells with good viability. These cells have greatly increased its population even forming a colony. The fact of forming a colony suggests that these cells have the capacity to form tissues and organs. 


\section{References}

1. Alexander HB. The mythology of all races. North American Mythology; 1916.

2. Soares AP, Knop LAH, Jesus AA, Araujo TM. Células-tronco em Odontologia. Rev Dental Press Ortodon Ortop Facial. 2007;12(1):3340 .

3. Bittencourt RAC, Pereira HR, Felisbino SL, Murador P, Oliveira APE, Deffune E. Isolamento de Células tronco mesenquimais da medula óssea. Acta Ortop Bras. 2006;14(1):22-4.

4. Landsdorp PM. Telomere length and proliferation potential of hematopoietic stem cells. J Cell Sci. 1995;108:1-6.

5. Nadin BM, Goodell MA, Hirschi KK. Phenotype and hematopoietic potential of side population cells throughout embryonic development. Blood Res. 2003;102:2436-43.

6. Kond M, Wagers AJ, Manz MG, Prohaska SS, Scherer DC, Beiihack GF, Shizuru JA, Weissman IL. Biology of hematopoietic stem cells and progenitors: Implications for clinical application. Ann Rev Immunol Res. 2003;21:759-806.

7. Weissman IL. The road ended up at stem cells. Immunol Rev Res. 2002;185:159-74.

8. Laughlin MJ, Barker J, Bambach B. Hematopoietic stem-cell transplants using umbilical-cord blood. New Engl J Med Res. 2004;344:1815-22.

9. Kershall EE, Flier JS. Adipose tissue as an endocrine organ. J Clin Endocrinol Metabol Res. 2004;89:2548-56.

10. Zuk P, Zhu M, Mizuno H, Huang J, Futrell JW, Katz AJ, Prosper B, Lorenz HP, Hedrick MH. Multilineage cells from human adipose tissue: implications for cellbased therapies. Tissue Eng. 2001;7(2):211-28.

11. Dani C. Stem cells from human adipose tissue: a new tool for pharmacological studies and for clinical applications. J Soc Biol Res. 2006;200(1):45-50.

12. Gregoire FM, Smas CM, Sul HS. Understanding adipocity differentiation. Physiol. Res. 1998;78(3):783-809.
13. Leri A, Kajstura J, Anversa P. Cardiac stem cells and mechanisms of myocardial regeneration. Physiol Rev. 2005;85:1373-416.

14. Forriol F, Esparza R. Ingeniería tisular: aplicación de las células troncales pluripotenciales em cirúgia ortopédica y traumatológica. Trauma Fund MAPFRE. 2008;19(2):88-101.

15. Friedenstein AJ, Chailakhjan RK, Lalykina KS. The development of fibroblast colonies in monolayer cultures of guinea-pig bone marrow and spleen cells. Cell Tissue Kinet. 1970;3:393-403.

16. Owen M. Marrow stromal cells. J Cell Sci. 1988;10:63-76.

17. Javazon EH, Colter DC, Schwarz EJ, Prockop DJ. Rat marrow stromal cells are more sensitive to plating density and expand more rapidly from single-cell-derived colonies than human marrow stromal cells. Stem Cells. 2001;19(3):219-25.

18. Hung SC, Chen NJ, Hsieh SL, Li H, Ma HL, Lo WH. Isolation and characterization of size-sieved stem cells from human bone marrow. Stem Cells. 2002;20(3):249-58.

19. Johnstone B. Point of view. Spine. 2002;27(12):1324.

20. Chen RR, Mooney DJ. Polymeric growth factor delivery strategies for tissue engineering. Pharm Res. 2003; 20(8):1103-12.

21. Muraglia A, Cancedda R, Quarto R. Clonal mesenchymal progenitors from human bone marrow differentiate in vitro according to a hierarchical model. J Cell Sci. 2000;113(7):1161-6.

22. Simonsen JL, Rosada C, Serakinci N, Justesen J, Stenderup K, Rattan SI, Jensen TG, Kassem M. Telomerase expression extends the proliferative life-span and maintains the osteogenic potential of human bone marrow stromal cells. Nat Biotechnol. 2002;20(6):592-6.

23. Rubio D, Garcia-Castro J, Martín MC, de la Fuente R, Cigudosa JC, Lloyd AC, Bernad A. Spontaneous human adult stem cell transformation. Cancer Res. 2005;65(8):3035-9.

24. Crisostomo PR, Wang M, Wairiuko GM, Morrell ED, Terrell AM, Seshadri P, Nam UH, Meldrum DR. High passage number of stem cells adversely affects stem cell activation and myocardial protection. Shock. 2006; 26(6):575-80.

\section{Correspondence:}

Lilian Piñero Eça

Av. Bem-te-vi, 333/134

04524-030 Sao Paulo-SP Brazil

Phone: (55 11)9456-0300

lilian@ipctron.com.br

\section{How to cite this article}

Mazzetti MPV, Oliveira IS, Miranda-Ferreira R, Fauaz G, Ribeiro CN, Gomes PO, Pontes P, Ferreira AT, Eça LP. Qualitative and quantitative analysis of rabbit's fat mesenchymal stem cells. Acta Cir Bras. [serial on the Internet] 2010 Jan-Feb;25(1). Available from URL: http:// www.scielo.br/acb 